\title{
GENETIC VARIATION OF TEAK MISTLETOE (Dendrophthoe pentandra (L.) MIQ.) BASED ON RANDOM AMPLIFIED POLYMORPHIC DNA (RAPD) MARKERS**
}

\author{
ZAINAL MUTTAQIN ${ }^{1 *}$, SRI WILARSO BUDI², BASUKI WASIS², \\ ISKANDAR ZULKARNAEN SIREGAR² AND CORRYANTI ${ }^{3}$ \\ ${ }^{1}$ Faculty of Forestry, Universitas Nusa Bangsa, Bogor 16161, Indonesia \\ ${ }^{2}$ Department of Silviculture, Faculty of Forestry, IPB University, Bogor 16680, Indonesia \\ ${ }^{3}$ Study Program of Environmental Sciences, Graduate Program, Institut Teknologi Yogyakarta, Yogyakarta 55171, Indonesia
}

Received 31 January 2019 / Accepted 21 May 2019

\begin{abstract}
Mistletoes are hemiparasitic macroparasite plants which interfere with trees and other wild plants in nutrient acquisition. As the plant has low leaf water potential, it draws water from teak wood tissues during the deciduous stage of the teak host, thereby killing the twigs and eventually, the teak tree. Mistletoes are also a key player in plant diversity. Therefore, the mistletoe population needs to be regulated not only as a parasite but also as a keystone species affecting biodiversity. Knowledge scarcity on the status of mistletoes includes its genetic variation. Hence, the purpose of this study is to analyze the level of genetic variation of teak mistletoe (Dendrophthoe pentandra) using RAPD marker. At Padangan teak Clonal Seed Orchard (CSO), it was randomly collected leaf samples from three layers of the mistletoe's crown (upper, middle, and below) were taken from five host teak trees randomly selected from each of the sub-observation measure plots (OMP). Four OMP units inside the observation sample plots (OSP) $(\mathrm{n}=3,50 \times 50 \mathrm{~m})$ at different levels of infestation (light, moderate and heavy) were established. Analysis of the genetic variation and genetic distance of mistletoes hanging on the different crown layers were conducted using RAPD markers. The leaf samples from the crown layers, UU (upper crown and sub-section upper), UM (upper crown and sub-section middle), and UB (upper crown and sub-section below), which include $\mathrm{U}$ (upper crown) had significantly greater genetic variation $(\mathrm{He}=0.181-0.255)$ than those from $\mathrm{M}$ layer (middle crown, $\mathrm{He}=0.227$ ) and the $\mathrm{B}$ layer (below crown, $\mathrm{He}=0.114$ ). Furthermore, the widest genetic distance significantly occurred between the mistletoes of the UB and B crown layers (0.310), whereas the nearest genetic distance significantly occurred between mistletoes of UU and UM layers in the upper crown (0.038). Practical implications of the low genetic variation in this study include the control of mistletoe $D$. pentandra infestation by means of restricting its population so that Perhutani State Owned Forestry Enterprise can maintain the level of damage below the economic threshold.
\end{abstract}

Keywords: Dendrophthoe pentandra, genetic variation, mistletoe, RAPD, Teak

\section{INTRODUCTION}

Mistletoes are hemiparasitic macroparasite plants which interfere in the nutrient acquisition of cultivated plants including trees and other wild plants. Based on their habitat, mistletoes attach themselves to certain parts of a host plant, such as branches, twigs, and occasionally stems. Many research aspects about mistletoe

${ }^{*}$ Corresponding author, e-mail: znldeg@yahoo.com

${ }^{*}$ This paper was presented at the $3^{\text {rd }}$ International Conference on Tropical Biology 2018, 20-21 September 2018, Bogor, West Java, Indonesia interaction with their hosts and bird dispersers have been conducted in both plantation and natural forest ecosystems. However, there is a lack of information concerning the effect of environmental variability of the canopy on the fate of mistletoe seeds and seedlings growth (Mellado \& Zamora 2014b), include aspect of genetic variation in this study and DNA barcode characterization (Muttaqin et al. 2017).

Mistletoe infestations can decrease the production of quality seeds in seed orchards and in timber plantations. Alarmingly, with repeated infestations, mistletoes can kill the host trees. 
The initial process of growth and development of mistletoes takes place when mistletoe seeds spread on those parts of stem by the assistance of birds as main agents (Mellado \& Zamora 2014a). The seeds then germinate and develop to form the haustorium organ which penetrates into the xylem of a host (xylem tapping) to absorb important nutrients such as water, minerals, and components of sugar and amino acids.

A study on the ecophysiology of teak and its canopy hemiparasite Dendrophthoe falcata var. pubescens revealed that mistletoes always maintain lower leaf water potential compared to the host teak. During the deciduous stage of the host teak, the mistletoe is drawing most of the water from the neighbouring wood tissue, thereby causing death of the twigs, and finally the death of the teak. The water use efficiency of the mistletoe is lower compared to that of the teak. Its photosynthetic performance concerning electron transport ability and quantum-energyuse efficiency are better in the mistletoe leaves. Since $\mathrm{K}$ and $\mathrm{Na}$ are phloem mobile minerals, these are highly concentrated in the misletoe leaves. That is indicative of the absence of any phloem connections between the host and the mistletoe. The mistletoe can photosynthesize at shade and exposed condition, showing its high adaptability to the host (Kallarackal et al. 2003). Moreover, mistletoe-host plants' antagonistic interactions, along with bird dispersers, may form complex networks whose function and structure can influence fragmentation at different scales, e.g., molecular or population levels (Arroyo et al. 2013).

In the Central Oregon, USA, pruning was effective in controlling the severity of dwarf mistletoes and in increasing the longevity of Douglas-fir, even if not all the misteltoes were removed because of the delayed mistletoe intensification (Maffei et al. 2016). In Perhutani, mistletoe control by silvicultural method was also applied by planting 'kersen' (Muntingia calabura), together with kesambi plant, dowet (Syzygium cumini) and salam (Syzygium polyanthum), as edge and filler plants. These plants, serving as substitute hosts of teak, have fruits which are foraged by the primary agent of mistletoe dispersal, the cabai bird (Dicaeum sp). The mix planting of teak for mistletoe control was also conducted in Indonesia (Corryanti et al. 2012).
Three mistletoe species were found at Padangan teak clonal seed orchard (CSO), East Jawa Province, Indonesia, namely Dendrophthoe pentandra (Loranthaceae), Macrosolen tetragonus (Loranthaceae), and Viscum articulatum (Santalaceae) (Muttaqin et al. 2017). D. pentandra was the most numerous and the most widely distributed at the orchard. Those mistletoes belong to indigenous plant groups that usually grow on suitable host plants and spread to tropical regions including Indonesia's forested areas.

The main goal of sustainable management at Padangan orchard is to control mistletoe infestation and develop immediate conservation measures. It requires synergistic, not antagonistic, support through the conservation of genetic variation of teak mistletoes which can be a valuable input and be correlated with the result of assessing the intensity of mistletoe infestation, including the True Mistletoe Rating (TMR) modified 8-class rating requirement (Muttaqin 2016). Sustainable management also requires accurate data or information on the level and range of mistletoes genetic variation that validates the presence or scarcity of mistletoe species exhibiting mistletoe main characters and high level of adaptation to environmental changes. The value of high genetic variation would take effect towards species ability to adapt on environmental condition, and vice versa. So as, this study hypothesis has two alternatives; if genetic variation of $D$. pentandra is low then the control of this mistletoe would be restricted to moderate and heavy infestation. If the genetic variation is moderate until high then the control of this mistletoe would be conducted against all levels of infestation from light, to moderate, to heavy. Therefore, knowledge about the genetic variation in mistletoes will improve the sustainable management of teak seed orchards, especially protection from pests and diseases, like mistletoes. Also, it be constitute candidate population for inclusion in future conservation programmes for mistletoe of Dendrophthoe pentandra that grow on teak stand in Perhutani area, Indonesia.

For genetic resource conservation, the genetic diversity and population structure of mistletoe $D$. pentandra need immediate investigation (Kim et al. 2017). Studies on the 
genetic variation of mistletoes had applied some markers such as RAPD, Microsatellite, AFLP (Crichton et al. 2012; Yi et al. 2013; Amico et al. 2014; Kim et al. 2017) and the study on the desert mistletoe Phoradendron californicum (Santalaceae) had used isolation of 18 Microsatellite loci (Arroyo et al. 2013). Despite the ecological and medical importance of $D$. pentandra, only few studies were conducted (Poerba \& Sunaryo 2006) and no studies have evaluated the genetic diversity of its wild populations in Indonesia. Therefore, this research was conducted to analyze the level of genetic variation of teak mistletoe $D$. pentandra using the Random Amplified Polymorphic DNA (RAPD) marker.

\section{MATERIALS AND METHODS}

\section{Sampling Sites}

The field data gathering and genetic material sampling were conducted at the Padangan teak CSO compartments or blocks, located at $111^{\circ} 34^{\prime} 57.3^{\prime \prime} \mathrm{E}$ and $07^{\circ} 12^{\prime} 56.1^{\prime \prime} \mathrm{S}$ and also at Bancer and Payaman Villages, Ngeraho District, Bojonegoro Regency, East Java Province, Indonesia (Fig. 1). The teak CSO area was divided into eight compartments that are further divided into blocks. A total of 132 blocks, at \pm 5 ha each totalling to \pm 660 ha, were established. Some 144 clones were planted repeatedly in the blocks from 1983 until 1996 (Corryanti 2015).
The molecular analysis was carried out at the Genetics and Forestry Molecular Laboratory, Silviculture Department, Faculty of Forestry, IPB University, Indonesia.

\section{Collection of Samples}

Leaf samples of $D$. pentandra were randomly collected from five host teaks randomly selected from the observation measure plots (OMP subplots). Four OMPs were established at the observation sample plots (OSP units) ( $\mathrm{n}=3,50$ $\mathrm{x} 50 \mathrm{~m}$ in size) depending on the level of infestation (light, moderate and heavy) (Muttaqin 2016), but one control OSP plot was not included because there was no infestation or no leaf samples of $D$. pentandra were found, referring to modified EFF or TS/CRC990 (Drescher et al. 2016) (Figs. 1, 2a, 2b). The number and distribution of mistletoe leaf samples were collected from the crown layers of each host teak. The crown layers consisted of UU (upper and sub-section upper), UM (upper and sub-section middle), UB (upper and subsection under), $\mathrm{M}$ (middle), and $\mathrm{B}$ layer (below). The number of collected samples (n) for each layer were $\mathrm{UU}(\mathrm{n}=45), \mathrm{UM}(\mathrm{n}=57), \mathrm{UB}(\mathrm{n}=$ 31), $M(n=56)$, and $B(n=15)$ totalling to 2014 leaf samples of $D$. pentandra. That procedure included the use of binoculars, digital cameras, GPS of Garmin Oregon 550 and a map of mistletoe infestation at Padangan teak CSO with scale $1: 18,000$ covering the infestation from years 2010-2014.

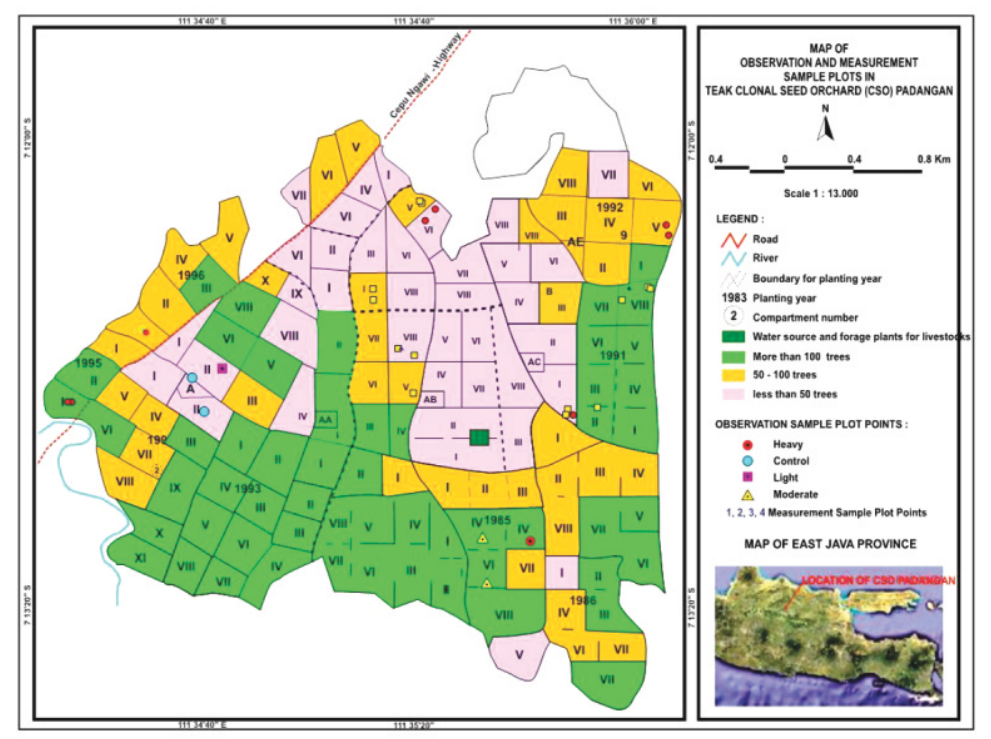

Figure 1 Location map of OSPs at the OMP in Padangan teak CSO (Muttaqin 2016) 


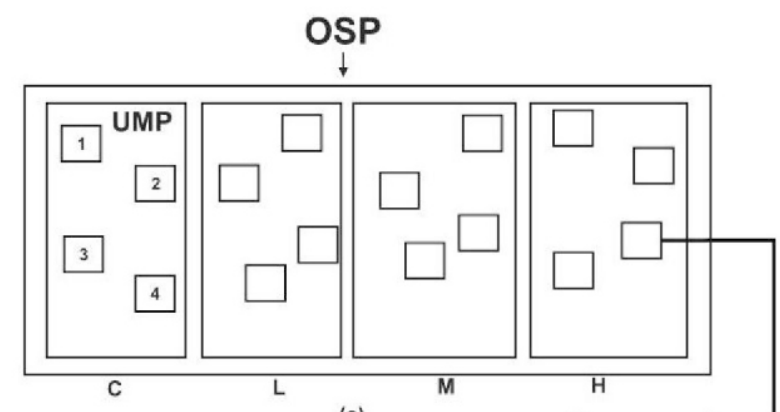

(a)

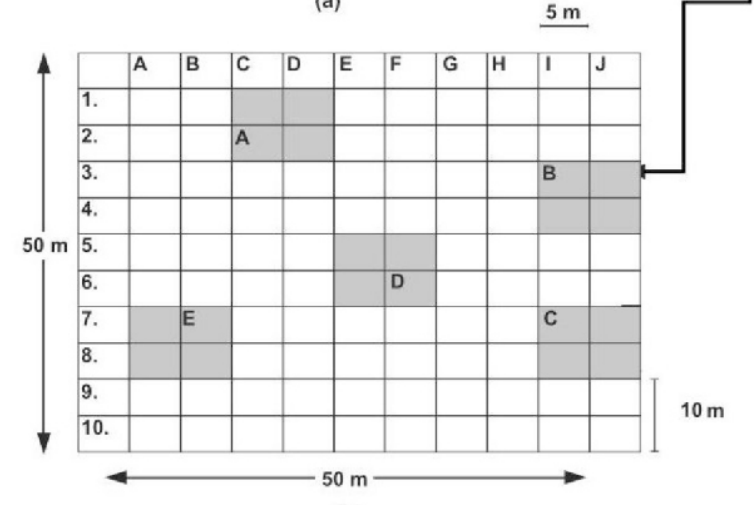

(b)

Figure 2 Field layout of the sampling units: (a) Position of the OMPs ( $n=4)$ in the OSP units; (b) Position of the subOMPs ( $\mathrm{n}=5$ ) in an OMP unit (source: EFForTS/CRC990 2012, modified for this research)

Notes: $\mathrm{C}=$ control; $\mathrm{L}=$ light; $\mathrm{M}=$ medium; $\mathrm{H}=$ heavy.

\section{Laboratory Procedures}

DNA was extracted from leaf samples and isolated using the modified CTAB (Cetyltrimetyl ammonium bromide) method (Doyle 1991; Aritonang et al. 2007). DNA quality was carried by PDA (Potato Dextrose Agar) electrophoresis of $1 \%$ agarose gel at 100 volts using the buffer TE $50 \mu \mathrm{L}, 3 \mu \mathrm{L}$ DNA and $2 \mu \mathrm{L} \mathrm{BJ}$ (Blue Juice).
The product of electroforesis was given the solution Gelred Tm nucleid acid and photographed on UV transiluminator model TFX-20.LM following Aritonang et al. (2007). Five random universal primers, namely; OPP-9, OPP-15, OPP-19, OPBH-20, OPBH-16, and 10 primers used by Amico et al. (2014) for Tristeric corymbosus (Loranthacea) of same family as D. pentandra were used in this research (Table 1).

Table 1 Tested primers and base sequences for the PCR-RAPD analysis of $D$. pentandra

\begin{tabular}{ccc}
\hline No. & Primers & $\begin{array}{c}\text { Base sequences } \\
\left(5^{\prime}-3^{\prime}\right)\end{array}$ \\
\hline 1 & OPP-9* & GTGGTCCGCA \\
2 & OPP-15* & GGAAGCCAAC \\
3 & OPP-19* & GGGAAGGACA \\
4 & OPBH-20* & CACCGACATC \\
5 & OPBH-16* & CTGCGGGTTC \\
6 & OPA-17 & GACCGCTTGT \\
7 & OPB-04 & GGACTGGAGT \\
8 & OPB-07 & GGTGACGCAG \\
9 & OPB-12 & CCTTGACGCA \\
10 & OPB-15 & GGAGGGTGTT \\
11 & OPA-04 & AATCGGGCTG \\
13 & OPB-18 & CCACAGCAGT \\
14 & OPB-20 & GGACCCTTAC \\
15 & OPF-11 & TTGGTACCCC \\
\hline
\end{tabular}

Note: $*$ primer selected for this study (Kissinger 2013; Amico et al. 2014). 
Table 2 Amplification steps of the PCR-RAPD marker

\begin{tabular}{cccc}
\hline Stages & $\begin{array}{c}\text { Temperature } \\
\left({ }^{\circ} \mathrm{C}\right)\end{array}$ & $\begin{array}{c}\text { Time } \\
\text { (minutes) }\end{array}$ & Cycle \\
\hline Pre-denaturation & 92 & 5 & 1 \\
Denaturation & 92 & 1 & $35^{\mathrm{a}} ; 45^{\mathrm{b}}$ \\
Annealing & $32 ; 35$ & 1 & 1 \\
Extension & 73 & 1 & 1 \\
Final Extension & 73 & 10 & 1 \\
\hline
\end{tabular}

Notes: a PCR machine at MJ Research PTC-100; b PCR machine at AB Applied Biosystem VeritiTM Thermal Cycler.

The primers were selected by temperature optimization (annealing) with the PCR process ranging from $32{ }^{\circ} \mathrm{C}, 33{ }^{\circ} \mathrm{C}, 34^{\circ} \mathrm{C}, 35^{\circ} \mathrm{C}, 36{ }^{\circ} \mathrm{C}$, to $37{ }^{\circ} \mathrm{C}$. Through electrophoresis, the five primers, i.e., OPP-9, OPP-15, OPP-19, OPBH-20, OPBH-16 showed clear DNA fragment bands at optimization temperature of $32{ }^{\circ} \mathrm{C}$ and $35^{\circ} \mathrm{C}$ with 35 and 45 cycles (Tables 1 and 2). However, the other primers obtained unclear DNA fragment bands. The primers used were then diluted $(5 \mathrm{x}, 10 \mathrm{x})$ or as ratios 1:50, 1:100 in $\mathrm{ddH}_{2} \mathrm{O}$ to elucidate the crystals of DNA bands by electrophoresis as a mixture of materials in a microtube for the PCR-RAPD process. Ingredients in the PCR-RAPD process of $1 \mathrm{x}$ reaction comprised of $\mathrm{Psd} \mathrm{H}_{2} \mathrm{O}(2.0 \mu \mathrm{L})$, Go Taq ${ }^{\circledR}$ Green Master Mix $(6.0 \mu \mathrm{L})$, Primer oligonucleic $(2.0 \mu \mathrm{L})$, DNA template $(2.0 \mu \mathrm{L})$.

The amplified PCR-RAPD marker was identified by electrophoresis using $2 \%$ agarose gel in $50 \mu \mathrm{L}$ TE buffer, $3 \mu \mathrm{L} \mathrm{DNA}$, and $2 \mu \mathrm{L}$ BJ (Blue Juice) for $45 \mathrm{~min}$ at 100 volts. The yields of the electrophoresis were given a Gelred Tm nucleic acid solution and were photographed on the UV transilluminator TFX-20. LM model (Nybom et al. 2014; Aritonang et al. 2007) to identify the clear bands.

The scoring used for locus marker was 1 if having a band and 0 if having no band. Further interpretation of each primer was carried out using the software POPGENE version 1.31 and NTSYSpc version 2.02. POPGENE was also used to compute for other statistics (e.g. allele frequency, gene diversity, genetic distance, F- statistics, multilocus structure. Meanwhile, NTSYS NTSYSpc was used in the cluster analysis of qualitative molecular genetic data (Rohlf 1998; Yeh et al. 1999; Aritonang et al. 2007).

\section{RESULTS AND DISCUSSION}

\section{Genetic Variation}

The 204 PCR amplified samples, using the five RAPD markers (OPBH 16, OPBH 20, OPP 9, OPP 15, and OPP 19), produced 46 clear polymorphic DNA bands (loci) with the base length ranging from 50 to $1500 \mathrm{bp}$ in size (Fig. 3). Each primer produced a range of 8 to 11 loci (mean of 9.2 loci), and the polymorphic loci percentage (PLP) ranged from 32.61 to $86.96 \%$ (Table 4). These results confirmed those in the study conducted by Poerba and Sunaryo (2006) on the same D. pentandra on 22 hosts, excluding teak, at Eka Karya Botanical Garden, Bali. Different from those used in this study, their study used two primers consisting of OPA11 which produced 12 polymorphic bands (PLP $100 \%$ ) and OPC-12 which produced 9 bands with 8 polymorphic bands (PLP 88.89\%) and 1 monomorphic band. Both primers have bands ranging from 150 to $1700 \mathrm{bp}$ in size. The same primer for predicting the genetic variation of Nepenthes gracilis Korth. in Kerangas Forest, Indonesia, produced a band ranging from 150 to $1400 \mathrm{bp}$ in size and PLP of $\geq 82.75 \%$ (Kissinger 2013). 


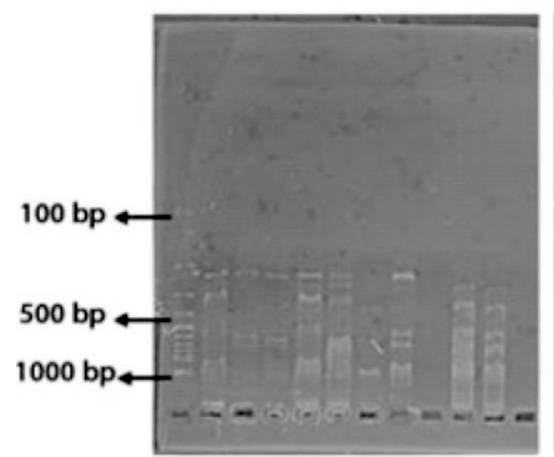

(a)

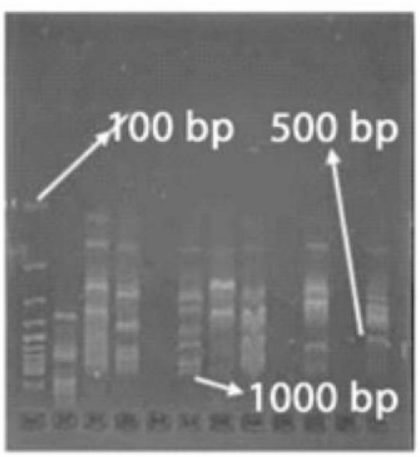

(b)

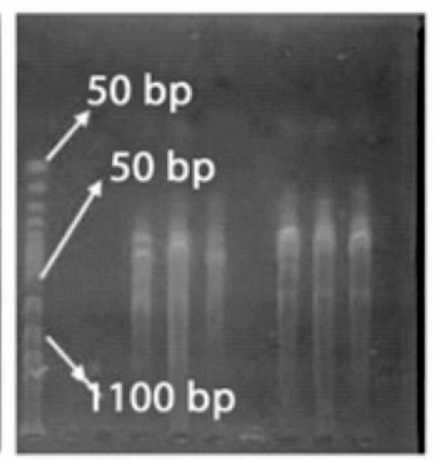

(c)

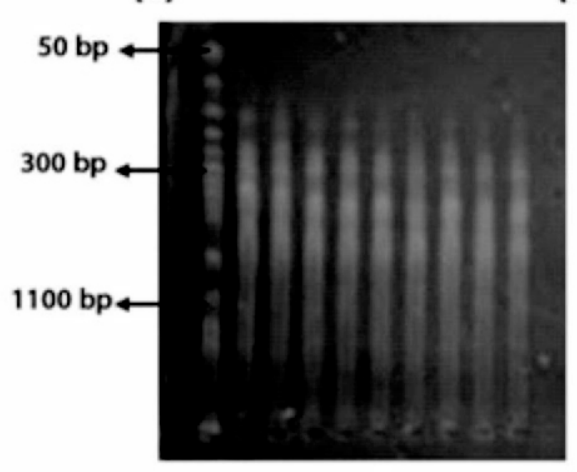

(d)

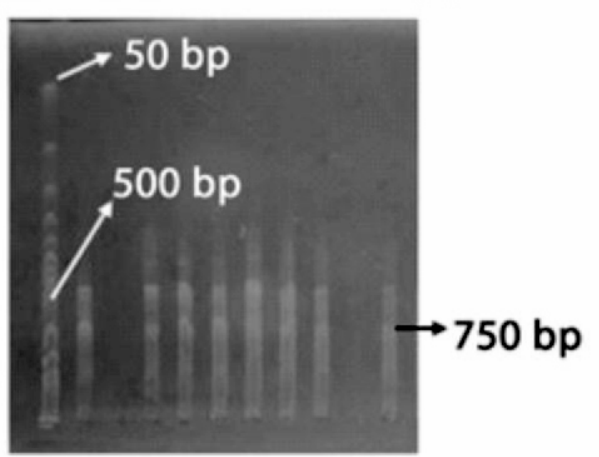

(e)

Figure 3 PCR amplification pattern with five markers: (a) OPBH 16, (b) OPBH 20, (c) OPP 9, (d) OPP 15, and (e) OPP 19

Table 3 The primer sequence and number of polymorphic bands

\begin{tabular}{lcccc}
\hline No & Primer & Sequence & $\begin{array}{c}\text { Number of } \\
\text { polymorphic bands }\end{array}$ & $\begin{array}{c}\text { Base length } \\
\text { (bp) }\end{array}$ \\
\hline 1 & OPBH 16 & 5'CTGCGGGTTC '3 & 8 & $50-1500$ \\
2 & OPBH 20 & 5' CACCGACATC '3 & 10 & $100-1500$ \\
3 & OPP 9 & 5' GTGGTCCGCA '3 & 11 & $50-1500$ \\
4 & OPP 15 & 5' GGAAGCCAAC '3 & 8 & $100-1100$ \\
5 & OPP 19 & 5' GGGAAGGACA '3 & 9 & $50-1100$ \\
\hline
\end{tabular}

Based on the five parameters of genetic diversity $\left(\mathrm{H}_{\mathrm{e}}\right)$ within population, the highest value $(0.255)$ was obtained by those mistletoes in the UM crown layer and the lowest (0.114) was obtained by those in the $\mathrm{B}$ crown layer (Table 4). The higher the $\mathrm{H}_{e}$, the higher is the Shannon index (I) and the $\mathrm{N}_{\mathrm{e}}$ (the sum of effective alleles). In addition, genetic variation of those in the UU, UM, and UB crown layers which have the upper crown sections $\left(\mathrm{H}_{\mathrm{e}}=\right.$ $0.181-0.255)$ are greater than those in the $\mathrm{M}$ layer (middle crown) $\left(\mathrm{H}_{\mathrm{e}}=0.227\right)$ and $\mathrm{B}$ layer (below crown) $\left(\mathrm{H}_{\mathrm{c}}=0.114\right)$. This indicated that the dispersal agent of mistletoe seeds, the birds cabai jawa (Dicaeum trochilium) and other specialist frugivores, preferred the upper and middle crown sections than the layer below (Muttaqin et al. 2016). The birds attached the seeds on branches and twigs through their bird droppings.

The $\mathrm{H}_{\mathrm{e}}$ value of $D$. pentandra using the RAPD marker was classified as rather low (0.194). This value was lower than Tristeric corymbosus using RAPD marker. Comparison with the different marker, It was lower than Arcethobium spp. and Viscum album using AFLP marker, also it lower than Ficus deltoidea using ISSR marker. However, It be within the range of $V$. coloratum $\left(\mathrm{H}_{\mathrm{e}}=\right.$ 0.032-0.672) using Microsatellite marker (Table 5). 
Table 4 Genetic variation using RAPD analysis of mistletoe Dendrophthoe pentandra (L.) Miq. at the different crown layers of infected host teak trees at Padangan teak CSO, Indonesia

\begin{tabular}{cccccccc}
\hline No & $\begin{array}{c}\text { Layer }^{\mathrm{a}} \\
\text { (crown part) }^{\mathrm{b}}\end{array}$ & $\mathrm{N}$ & $\begin{array}{c}\mathrm{PLP} \\
(\%)\end{array}$ & $\mathrm{Na}$ & $\mathrm{Ne}$ & $\mathrm{H}_{\mathrm{e}}$ & $\mathrm{I}$ \\
\hline 1 & $\mathrm{UU}$ & 45 & 60.870 & 1.609 & 1.306 & 0.181 & 0.273 \\
2 & $\mathrm{UM}$ & 57 & 86.960 & 1.870 & 1.429 & 0.255 & 0.391 \\
3 & $\mathrm{UB}$ & 31 & 65.220 & 1.652 & 1.323 & 0.192 & 0.295 \\
4 & $\mathrm{M}$ & 56 & 76.090 & 1.761 & 1.377 & 0.227 & 0.346 \\
5 & $\mathrm{~B}$ & 15 & 32.610 & 1.326 & 1.186 & 0.114 & 0.171 \\
\hline Sum & & 41 & 321.750 & 8.218 & 6.622 & 0.969 & 1.476 \\
Average on type level & 18 & 20.4350 & 1.644 & 1.324 & 0.194 & 0.295 \\
\multicolumn{2}{l}{ Standard deviation (SD) } & & 0.204 & 0.091 & 0.054 & 0.083 \\
\hline
\end{tabular}

Notes: a Irawan (2004), modified for this study: N = sum of samples; PLP = Polymorphic Locus Percentage; $\mathrm{Na}=$ sum of observed samples alleles; $\mathrm{Ne}=$ sum of effective alleles; He = Heterozygosity expectation; $\mathrm{I}=$ Shannon Index;

${ }^{\mathrm{b}} \mathrm{UU}=$ upper crown sub-section upper, $\mathrm{UM}=$ upper crown sub-section middle, $\mathrm{UB}=$ upper crown sub-section under; $\mathrm{M}=$ middle crown, $\mathrm{B}=$ below crown.

Table 5 Comparison of genetic variation of mistletoes in this study and other studies using RAPD and other markers

\begin{tabular}{lcccc}
\hline \multicolumn{1}{c}{ Species } & He & Marker & Origin & Source \\
\hline $\begin{array}{l}\text { Dendrophthoe pentandra } \\
\text { Tristerix corymbosus }\end{array}$ & 0.194 & RAPD & Indonesia, Padangan teak CSO & This study \\
$\begin{array}{l}\text { Malaysian mistletoe Fig } \\
\text { (Ficus deltoidea Jack) }\end{array}$ & 0.365 & RAPD & Chile & Amico et al. 2014 \\
Viscum album & $0.500-0.750$ & ISSR & Malaysia & Zimisuhara et al. 2015 \\
Arcethobium spp. Viscaceae & 0.238 & AFLP & Korea & Yi et al. 2013 \\
& & AFLP & Western North America, & Reif et al. 2015 \\
Melampyrum sylvaticum & $0.330-0.750$ & Microsatellite & The United Kingdom & Crichton et al. 2012 \\
Phoradendron californicum & $0.364-0.924$ & Microsatellite & Mexico & Arroyo et al. 2013 \\
Viscum coloratum & $0.032-0.672$ & Microsatellite & Korea, Japan, China & Kim et al. 2017 \\
\hline
\end{tabular}

The 19 novel polymorphic microsatellite markers for mistletoe Viscum coloratum have been developed for its use as anti-cancer medicinal plants and have become a novelty in the molecular analysis of mistletoes ( $\mathrm{Kim}$ et al. 2017). Fortunately, cross-species amplification indicated that those markers can also be used for molecular analysis associated with other species coming from the same family (Santalaceae). That result was also tested for cross-species amplification in $V$. articulatum as a potential medicinal plant.

The level of genetic variation of mistletoes play an important role in their capability to adapt to changes in environmental condition, such as lack of water, nutrient, and their regeneration. Low genetic variation implies a high sensitivity to heterogeneous environment that is detrimental to the growth and development of mistletoes. D. pentandra has a rather low genetic diversity (Table 4), therefore, it is important to maintain the genetic variation of $D$. pentandra in order to protect its existence and prevent it from extinction, and this requires effective conservation strategies. The massive utilization of $D$. pentandra as a medicinal plant is a cause of concern even as they are hanging on host tree and crops.

Genetic diversity estimates among and within populations of mistletoes species, will further help in the development of effective strategies for their conservation (Kim et al. 2017). The knowledge gained from research using Microsatellite markers was needed in designing conservation management programs for $M$. sylvaticum in the United Kingdom (Crichton et al. 2012). Such information will also be useful for other related species of endangered non-weedy hemiparasites, according to Mellado \& Zamora (2019), with similar traits and life history.

\section{Genetic Distance among Mistletoes on Different Canopy Layers}

The largest genetic distance (0.131) was obtained significantly between mistletoes hanging on the UB and $B$ layers which have different crown sections while the shortest genetic distance (0.038) was significantly between those at the UU and UM layers which were at the same upper crown sections (Table 6). 
Table 6 Genetic distances between mistletoes hanging on different crown layers of host teaks

\begin{tabular}{|c|c|c|c|c|c|}
\hline Crown layer & UM & $\mathrm{M}$ & $\mathrm{B}$ & UB & UU \\
\hline UM & ***** & & & & \\
\hline M & 0.041 & $* * * *$ & & & \\
\hline B & 0.119 & 0.100 & $* * * *$ & & \\
\hline UB & 0.092 & 0.065 & 0.131 & $* * * *$ & \\
\hline UU & 0.038 & 0.083 & 0.124 & 0.101 & $* * * *$ \\
\hline
\end{tabular}

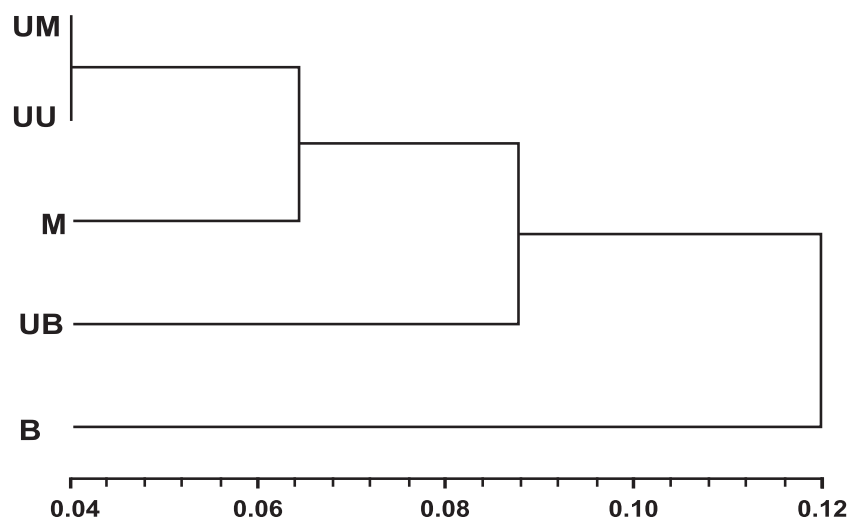

Figure 4 UPGMA dendrogram of the genetic distances, based on RAPD marker, of D. pentandra mistletoes growing on the different crown layers of teak

Notes: Crown layers: $\mathrm{UU}=$ upper crown sub-section upper, $\mathrm{UM}=$ upper crown sub-section middle, $\mathrm{UB}=$ upper crown sub-section under; $\mathrm{M}=$ middle crown, $\mathrm{B}=$ below crown.

The genetic distance or relatedness among mistletoes growing on different crown layers (described by a cluster or a dendrogram) were spread over a Eucledian distance consisting of eight units (0.04 - 0.13) (Fig. 4). Two different clades were identified in which the first clade consisted of mistletoes from the UM, UU, M, UB crown layers, while the second clade only contained those mistletoes in the B crown layer which was considered an outgroup. In this case, the mistletoes in the $\mathrm{B}$ layer were more genetically distant from other mistletoes in the UU (0.124), UM (0.119), UB (0.131), M (0.100) (Table 6). Hence, as predicted, the two clusters were of different genetic structure.

Another cluster analysis of $22 \mathrm{D}$. pentandra collected from several different locations had separated the samples into two clusters; one cluster consisted of 3 groups, namely; group 1 ( 6 collections), group 2 (13 collections), and group 3 (2 collections), whereas the other cluster, the outgroup, consisted of only 1 collection (Poerba \& Sunaryo 2006). The Euclidean distance was 43 units $(0.490-0.920)$ longer than this study result $(0.038-0.131)$. The different clustering is due to the different genetic distant that $D$. pentandra grow on teak and others as host tree on different locations. While in this study, $D$. pentandra grow only on teak of crown layers differently.

\section{CONCLUSION}

Based on the RAPD marker, the genetic variation, $H_{e}$, of $D$. pentandra mistletoe was rather low $\left(\mathrm{H}_{\mathrm{e}}=0.114-0.255\right)$. The highest $\mathrm{H}_{\mathrm{e}}(0.255)$ was found among the mistletoes of the upper middle layer of the canopy, UM layer, while the lowest $\mathrm{H}_{\mathrm{e}}(0.114)$ was among the mistletoes in the layer below the crown (B). The genetic distance in the five layers or sections of teak crown inhabited by $D$. pentandra ranged from 0.038 to 0.131 , and was clustered into two clades. The first clade consisted of mistletoes in the UM, UU, M, and UB layers, while the second clade consisted of those mistletoes in the B layer.

For Perhutani, the state-owned forestry enterprise, this study results practically implied the thorough removal of mistletoes by pruning them from the entire sections of the crown, as was done successfully on the dwarf mistletoes of Douglas fir. 


\section{ACKNOWLEDGEMENTS}

This study was supported by DIPA SEAMEO BIOTROP 2015 (No. 045.17/PSRP/ SC/SPK-PNLT/III/2015), Indonesia. The authors would like to also acknowledge and express their gratitude to Mr. Suwarno, the Head of Research and Development Center of Perhutani, Indonesia and his technical staff for their invaluable assistance during the field sample collection.

\section{REFERENCES}

Amico GJ, Vidal-Russell R, Aizen MA, Nickrent D. 2014. Genetic diversity and population structure of the mistletoe Tristerix corymbosus (Loranthaceae). Plant Syst Evol 300:152-62.

Aritonang KV, Siregar IZ, Yunanto T. 2007. Manual of genetic analysis of forest plant in Silviculture laboratory. Bogor (ID): Faculty of Forestry, IPB University.

Arroyo JM, Munguia-Vega A, Rodriguiz-Estrella R, Bascompte J. 2013. Isolation of 18 microsatellite loci in the desert mistletoe Phoradendron californicum (Santalaceae) via 454 pyrosequencing. Appl Plant Sci 1(12):1-4.

Corryanti, Purwanto, Suhudi M, Suryanaji, Mawardi K, Hartanto B. 2012. Study of mix planting in teak for controlling of mistletoe. Cepu (ID): Research and Development Center Perum Perhutani.

Corryanti. 2015. Character of teak trees in Clonal Seed Orchard. Cepu (ID): Research and Development Center Perum Perhutani.

Crichton RJ, Squirrell J, Woodin SJ, Dalrymple SE, Hollingsworth PM. 2012. Isolation of microsatellite primers for Melampyrum sylvaticum (Orobanchaceae), an endangered plant in The United Kingdom. American J Bot:e457-9.

Doyle J. 1991. DNA protocols for plants. New York (US): Bailey Hortorium 462 Mann Library, Cornell University.

Drescher J, Rembold K, Allen K, Beckschäfer P, Buchori D, Clough Y, ... Scheu S. 2016. Ecological and socio-economic functions across tropical land use systems after rainforest conversion [Abstract]. Phil Trans R Soc B 371(1694):20150275.

Irawan B. 2004. Ironwood (Eusideroxylon zwageri Teijsm. \& Binn.) and its varieties in Jambi, Indonesia [Dissertation]. Göttingen (DE): University of Göttingen.

Kallarackal J, Somen CK, Rajesh N. 2003. Teak and its canopy parasite Dendrophthoe - water relations and ecophysiology. In: Bhat KM, Nair KKN, Bhat KV,
Muralidharan EM, Sharma JK, editors. Quality Timber Products of Teak from Sustainable Forest Management. Proceedings of the International Conference. p. 188-97.

Kim BY, Park HS, Kim SN, Kim YD. 2017. Development of microsatellite markers for Viscum coloratum (Santalaceae) and their application to wild populations. Appl Plant Sci 5(1):1600102.

Kissinger. 2013. Bioprospection of heath forest: Analysis of Nepenthes gracilis Korth as conservation stimulus [Dissertation]. Retrieved from IPB University.

Maffei HM, Filip GM, Grulke NE, Oblinger BW, Margolis EQ, Chadwick KL. 2016. Pruning highvalue Douglas-fir can reduce dwarf mistletoe severity and increase longevity in Central Origon. Forest Ecol Manag 379:11-9.

Mellado A, Zamora R. 2014a. Generalist birds govern the seed dispersal of a parasitic plant with strong recruitment constraints. Oecologia 176:139-47.

Mellado A, Zamora R. 2014b. Linking safe sites for recruitment with host-canopy heterogeneity: The case of a parasitic plant, Viscum album subsp. Austriacum (Viscaceae). Am J Bot 101(6):000-000.

Mellado A, Zamora R. 2019. Ecological consequences of parasite host shifts under changing environments: More than a change of partner. J Ecol, in press.

Muttaqin Z. 2016. Karakter biologi benalu pada jati di Kebun Benih Klonal (KBK) Padangan, Perum Perhutani [Character of biology of mistletoe on teak in Clonal Seed Orchard (CSO), Padangan, Perum Perhutani (State Owned Forestry Enterprise)] [Dissertation]. Retrieved from IPB University.

Muttaqin Z, Budi SW, Wasis B, Siregar IZ, Corryanti. 2016. Peranan burung sebagai agen penyebaran benalu pada jati di Kebun Benih Klonal (KBK) Padangan, Perum Perhutani [Role of bird as agent of mistletoe spread in Padangan teak Clonal Seed Orchard (CSO), Perum Perhutani (State Owned Forestry Enterprise)]. Zoo Indonesia 25(2):90-106.

Muttaqin Z, Budi SW, Wasis B, Siregar IZ, Corryanti. 2017. DNA barcode characterization of mistletoe infestation in teak clonal seed orchard (CSO) in Padangan, East Java Province, Indonesia. BIOTROPIA 24(2):140-52.

Nybom H, Weising K, Rotter B. 2014. DNA fingerprinting in botany: Past, present, future. Investig Genet 5(1):1-35.

Poerba YS, Sunaryo. 2006. Genetic variation study of parasite Dendrophthoe pentandra (L.) Miq. based on random amplified polymorphic DNA marker. Bogor (ID): Technical Report. Scope Botany, Center of Biology Research, LIPI.

Reif BP, Mathiasen RL, Kenaley SC, Allan GJ. 2015. Genetic structure and morphological differentiation of three Western North American 
dwarf mistletoes (Arceuthobium: Viscaceae). SYST BOT 40(1):191-207.

Rohlf FJ. 1998. NTSYS-pc version 2.0. Numerical taxonomy and multivariate analysis system. New York (US): Exeter Software, Setauket, New York.

Yeh FC, Yang R-C, Boyle T. 1999. POPGENE version 1.31. Microsoft Windows-based freeware for population genetics analysis. Canada (CA): Department of Renewable Resources, University of Alberta, Edmonton, Alberta, Canada.
Yi JS, Kim CW, Lee JK, Meng FJ. 2013. Identification of populations of Korean mistletoe (Viscum album L. coloratum) from Gangwon-Do in Korea by AFLP. Biotechnol \& Biotechnol Eq 27(5):4091-7.

Zimisuhara B, Valdiani A, Shaharuddin NA, Qamaruzzaman F, Maziah M. 2015. Structure and principal components analyses reveal an Intervarietal fusion in Malaysian mistletoe fig (Ficus deltoidea Jack) populations. Int J Mol Sci 16:14369-94. 